\title{
Resistance in groundnut (Arachis hypogaea L.) to Aphis craccivora (Koch).
}

\author{
By D. E. PADGHAM, F. M. KIMMINS and G. V. RANGA RAO* \\ Natural Resources Institute, Central Avenue, \\ Chatham Maritime, Chatham, Kent ME4 4TB, UK \\ *International Crops Research Institute for \\ the Semi-Arid Tropics, Patancheru P.O., Andhra Pradesh 502 324, \\ India
}

(Accepted 18 July 1990)

\begin{abstract}
Summary
The behaviour, development and reproductive capacity of Aphis craccivora, vector of a number of groundnut viruses, are compared on a range of susceptible and resistant genotypes. Field trials demonstrated no significant difference between genotypes in the rate of arrival of alates, but population development was slower, and subsequent population decline faster, on the genotype EC 36892 (ICG 5240). Behavioural studies in the screenhouse, likewise showed no inhibition to alighting onto EC 36892 though choice tests demonstrated a significant redistribution of the population in favour of the susceptible genotype TMV 2 (ICG 221) over the following $10 \mathrm{~h}$. In clip cage experiments, development was faster and nymphal numbers were higher on the genotype TMV 2 compared to EC 36892.
\end{abstract}

Key words: Aphis craccivora, virus vector, groundnut, groundnut rosette, plant resistance

\section{Introduction}

Aphis craccivora (Koch) is a major pest of groundnut (Arachis hypogaea L.) causing yield losses by feeding on phloem sap and through the transmission of virus diseases (Feakin, 1973; Wightman \& Amin, 1988). It is the vector of at least seven viruses which attack groundnut, the most important of which are Groundnut Rosette Virus (GRV) in Africa and Peanut Stripe Virus (PStV) in Asia.

Host plant resistance to $A$. craccivora in groundnut is recognised as being an effective and economic method of limiting both the spread of the aphid and the spread of persistant viruses. Evans (1954) demonstrated that this factor restricted the spread of GRV in Tanzania and subsequent studies have confirmed this in Malawi (Anon., 1988). Amin (1985) suggested that resistance mechanisms in groundnut could deter colonisation by immigrant alatae and could also reduce their fecundity. Screening trials of germplasm from various regions by the International Crops Research Institute for the Semi-Arid Tropics (ICRISAT) have led to the identification of aphid resistant groundnut genotypes (Anon., 1987, 1988). Resistance to this aphid has been recorded and studied in other leguminous plants including cowpea (Vigna unguiculata (L.) (MacFoy \& Dabrowski 1984; Givovich, Weibull \& Pettersson, 1988) and Vicia $f a b a$ (L.) (Schnorbach, 1983) but little is known about groundnut resistance. A collaborative research programme to investigate these mechanisms has been established between the Natural Resources Institute (NRI) and ICRISAT. The data generated will assist plant breeders to develop cultivars with resistance to aphids.

(C) 1990 Association of Applied Biologists 
The objectives of this programme are to determine the factors in resistant groundnut genotypes which interfere with aphid plant selection and/or retard aphid growth and development. This paper describes the first phase of the work; field and laboratory studies of the distribution, behaviour and development of $A$. craccivora on six groundnut genotypes which are known to differ in their levels of resistance to this species (Anon., 1987).

\section{Materials and Methods}

\section{Location}

Field and greenhouse observations of aphid behaviour and development on resistant and susceptible groundnut genotypes were performed at the ICRISAT Centre, Patancheru, India during the kharif (rainy season), June-July 1988.

\section{Plants}

Four groundnut genotypes which differed in their levels of aphid resistance during field trials (ICRISAT) were selected for further investigation together with two genotypes with unknown levels of resistance.

Identity ICG number*

TMV 2 ICG 221 susceptible to $A$. craccivora

EC 36892 ICG 5240 highly resistant to $A$. craccivora

JL 24 ICG 7287 moderately resistant to $A$. craccivora

NC Ac 343 ICG 2271 moderately resistant to $A$. craccivora

GBPRS 15 ICGV 86030 unknown response

GBPRS 66 ICGV 86535 unknown response

${ }^{*}$ ICG - ICRISAT groundnut accession number

In the greenhouse, all seeds were treated with a fungicide, Thiram $(30 \mathrm{~g}$ a.i. $\mathrm{Kg}-1$ seed), prior to sowing in pots (150 mm diameter) containing a local alfisol. Seeds of EC 36892 were treated with Etheral, an ethylene releasing chemical to break dormancy.

\section{Insects}

Greenhouse sown groundnut plants (TMV 2) were infested with $A$. craccivora originating from field collected alates. Alate and apterous virginoparae were collected from these plants and used directly for the host selection and performance experiments which were carried out in a separate screenhouse with no supplementary illumination; dawn was at approximately 06.00 and dusk at 19.00. The mean temperature in the air-conditioned greenhouse and screenhouse during the experimental period was $28^{\circ} \mathrm{C} \pm 6^{\circ} \mathrm{C}$.

\section{Aphid distribution and numbers}

\section{(a) field observations}

The numbers of aphids and distribution of aphids on the six genotypes were recorded from a field site on the ICRISAT farm. Plots of the six groundnut genotypes were sown on 27 June 1988 in a randomised block design (area $22.5 \mathrm{~m} \times 45.5 \mathrm{~m}$ ). This accommodated four raised beds divided into 150 plots ( 25 plots per genotype, 100 seeds per plot each measuring $1 \mathrm{~m} \times 4 \mathrm{~m}$ and separated by furrows width $0.5 \mathrm{~m}$ ). The numbers of aphids on every plant in 90 randomly selected plots ( 15 plots per genotype) were counted in situ five times between 4 and 16 July 1988 . Plots on the perimeter were excluded from the sample to reduce the influence of edge effects on aphid distribution (Heathcote, 1972). 


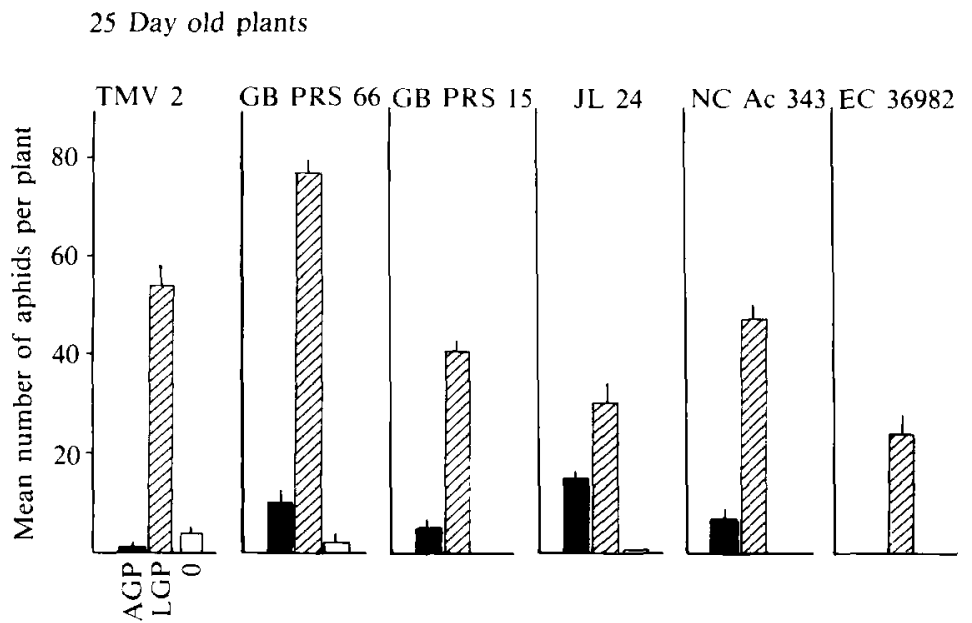

Fig. 1. The mean number of insects per plant ( $+/-$ S.E.) for each of the three plant part categories: Apical growth point, Lateral growth point,

\section{(b) greenhouse observations}

In determining the performance of individual aphids it is necessary to cage the insect on the plant. However, aphids invariably have preferred feeding sites on their host plant (Kennedy, Ibbotson \& Booth, 1950) and, as such, it was necessary to determine any such preferences shown by $A$. craccivora before the cage experiments were performed. Aphid distribution and density were quantified on greenhouse grown plants (age: 25 DAS) of the six groundnut genotypes, listed above, which had been placed in the field for colonisation by immigrant alatae. During the survey three categories of feeding site were recognised:

(1) The apical growth point:- the cluster of leaves at the apex of the plant. This was present in all genotypes.

(2) Lateral growth points:- the new leaf clusters at the terminus of each shoot arising laterally from the stem.

(3) Other:- all other vegetative parts of the plant including the main vertical stem, lateral stems and mature leaves.

For each plant part the total number of insects (nymphs, apterae and alates) were counted. Although six genotypes were examined, the principal purpose of this survey was to consider within plant choice, inter-genotype comparisons being complicated by different growth patterns and growth rates. For example, lateral branches developed sooner on plants of EC 36892 than on any other genotype.

Twenty plants of each genotype were examined and the results are presented in Fig. 1 as mean number of aphids per plant part.

In all genotypes there was a significant preference for the tips of the lateral shoots compared to either the apical growing points $(P<0.001)$ or the mature plant parts $(P<0.001)$. Therefore the lateral shoots of the plants were chosen for the assessment of aphid performance.

\section{Aphid performance}

The effect of plant factors on the development of individual aphids was measured by recording the number of days taken to reach reproductive maturity and the number of offspring produced in the first five days of reproductive life. Apterous virginoparae were individually confined in clip cages (Nobel, 1958) on young leaflets of lateral growing points. The adults 
were left to produce nymphs, and after $24 \mathrm{~h}$, the adults and all but one nymph per cage were removed with a fine paint brush. The remaining nymphs were observed daily to determine the number of days taken to reach reproduction and the number of offspring produced in five days thereafter. Only those nymphs becoming apterae were included in the results since alates tend to take longer to develop and produce fewer nymphs (Dixon, 1985). Two ages of plant were used 7-20 DAS and 25-43 DAS.

\section{Aphid plant selection}

Alate choice was examined by releasing groups of 200 alates into the centre of a mesh cage (height $0.4 \mathrm{~m}$, width $1 \mathrm{~m}$, depth $1 \mathrm{~m}$ ) containing a circle of potted groundnut plants, five pots of TMV 2 (susceptible) alternating with five pots of one of the other genotypes (test plants). Two plant ages were used, 8-12 DAS and 23-26 DAS with six replicates of each. The numbers of alates on each plant were counted at intervals of $1,2,4,6,8,10$ and $24 \mathrm{~h}$.

Choice tests for apterous aphids consisted of three plants (23-26 DAS) of TMV 2 and three of the other genotypes transplanted and spaced alternately around the edge of a pot (diameter $40 \mathrm{~cm}$ ). The plants were left for $24 \mathrm{~h}$ to counteract any effects of transplanting which could influence plant physiology, i.e. water stress. Fifty apterae were released in the centre of the pot and the numbers on each plant were counted $1,2,4,6,8,10$ and $24 \mathrm{~h}$ after release. This procedure was repeated using different arenas over eight days, i.e. eight replicates ( 400 insects) per genotype.

\section{Results}

\section{Aphid distribution and numbers}

\section{Field observations}

In the field the emergence rates of the six groundnut genotypes differed from one another. For example, at seven DAS, only one plant of EC 36892 had emerged $(0.06 \%$ of the potential population) while the other genotype had percentage emergence rates of between $14 \%$ to $35 \%$. The number of aphids counted was expressed as $n / 100$ plants (Fig. 2).

At seven DAS no comparisons could be made between the numbers of aphids on EC 36892 and those on the other genotypes because of the poor emergence rate of EC 36892. No aphids were found on GBPRS 66 and, on the other genotypes, only low numbers of nymphs and/or alates (approx. one aphid per 100 plants) were found.

By 10 DAS, $14 \%$ of the EC 36892 seeds had emerged and one apterous adult was found on these plants. Approximately one alate per 100 plants was counted on genotypes TMV 2, GBPRS 15, GBPRS 66 and JL 24 while fewer alates were found on plants of NC Ac 343. Apterae were present on plants of TMV 2, EC 36892, GBPRS 66 and JL 24 while nymphs were found on all genotypes except EC 36892. TMV 2 and JL24 carried the highest densities at this stage. At 13 DAS, similar proportions of alates were counted on plants of all ages, but fewest apterae and nymphs were found on EC 36892.

At 16 DAS there were proportionally more alates on EC 36892 than on any other genotype and the numbers of apterae and nymphs also showed a marked increase. Relatively few apterae and nymphs were counted on genotypes GBPRS 15 and NC AC 343.

At 19 DAS, a large reduction (mean of 64\%) in the numbers of aphids (apterae, alates and nymphs) was noted on all genotypes but most dramatically on EC $36892(85 \%)$. Heavy rainfall was recorded on the previous night and this appeared to have washed the insects from the plants. 

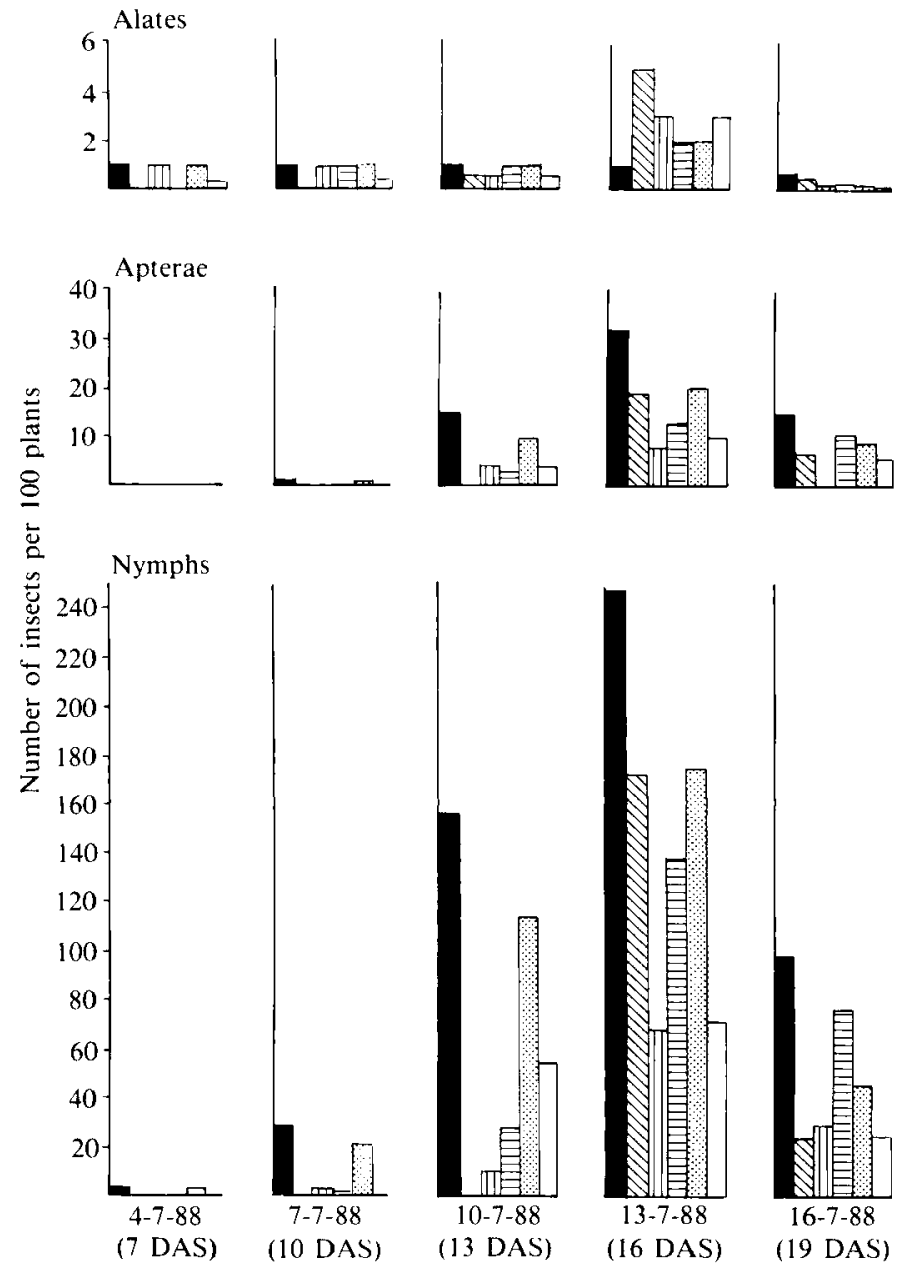

Fig. 2. Changes in the numbers of alates, apterae and nymphs on field plots of six genotypes over the period from sowing to 19 days after sowing: TMV 2, EC 36892, GBPR 15, JL 24, J NC Ac 343, $\square$.

\section{Aphid performance}

Insects cages on EC 36892 took longer to develop and produced fewer offspring than those on any genotype (Table $1 a$ and $b$ ). On EC 36892, the insects took approximately one day longer to reach reproductive maturity and produced $70 \%$ fewer nymphs than on TMV 2. Significantly fewer nymphs were also produced by apterae on genotypes GBPRS 15 and NC Ac 343 (7-20 DAS) than on either TMV 2 or JL 24 (Table $1 a$ ), although there were no differences between the number of days taken to reach reproduction. On older plants (25-43 DAS) significantly more offspring were recorded on TMV 2 than on any other genotype (Table $1 b$ ). Comparisons of of fspring produced on the two ages of the same genotype revealed only one significant difference; on JL $24,23 \%$ fewer nymphs were produced on older plants (25-43 DAS) than on 7-20 DAS plants $(P<0.01)$. 
Table 1. Number of days taken to reach reproduction and number of offspring produced in first 5 days of reproductive life (means $+/-$ S.E.) by A. craccivora on two ages of six groundnut genotypes. Means followed by the same letter are not significantly different

$$
(P>0.05)
$$

Plant age Cultivar

N

$$
\text { a.7-20 }
$$$$
\text { DAS }
$$

DAS

$$
\text { b.25-43 }
$$

DAS

TMV 2
JL 24
GBPRS 66
GBPRS 15
NC Ac 343
EC 36892
TMV 2
GBPRS 66
JL 24
GBPRS 15
NC Ac 343
EC 36892

$\mathbf{N}$

\section{7}

18

19

20

19

15

23

17

19

13

16

18

$$
\begin{aligned}
& \text { No. of days } \\
& \text { to reproduction } \\
& \text { 5.2a }(0.1) \\
& 5.3 \mathrm{a}(0.1) \\
& 5.6 \mathrm{a}(0.2) \\
& 5.7 \mathrm{a}(0.3) \\
& 5.8 \mathrm{ab}(0.1) \\
& 6.4 \mathrm{~b}(0.3) \\
& 5.7 \mathrm{a}(0.1) \\
& 6.0 \mathrm{a}(0.3) \\
& 6.1 \mathrm{a}(0.2) \\
& 6.2 \mathrm{a}(0.2) \\
& 6.2 \mathrm{a}(0.3) \\
& 7.5 \mathrm{~b}(0.3)
\end{aligned}
$$

No. of offspring

42.5a (2.6)

$41.9 \mathrm{a}(1.7)$

$37.1 \mathrm{ab}(2.0)$

$31.2 \mathrm{bc}(2.9)$

$28.0 \mathrm{c}(1.7)$

$12.0 \mathrm{~d}(1.8)$

43.5a (2.6)

$35.3 \mathrm{~b}(2.2)$

$32.3 \mathrm{bc}(2.8)$

$32.0 \mathrm{bc}(4.6)$

$24.7 \mathrm{c}(3.0)$

$10.7 \mathrm{~d}(1.6)$

\section{Aphid host plant selection}

\section{Alates}

Between $43 \%$ and $72 \%$ of the alates were found on the sides, upper and lower surfaces of the mesh cages and on plant pots. These individuals have been excluded from the chi-square calculations.

Over the $24 \mathrm{~h}$ period, alates were equally distributed between TMV 2 and each of three other genotypes, NC Ac 343, GBPRS 15 and JL 24 (Table 2a). Shifts in alate numbers between TMV 2 and GBPRS 66 suggested that there was no clear preference for either genotype. However, significantly more alates were counted on EC 36892 than on TMV 2 over the first four $h$ : at six $h$ there was no significant difference and at 8,10 and $24 \mathrm{~h}$ significantly more were found on TMV 2 than on EC 36892 (Fig. 3). This indicates that plants of EC 36892 are initially more attractive to alates but they moved off this genotype such that more were found on TMV 2 after $24 \mathrm{~h}$.

\section{Apterae}

Apterae dispersed around the arena quickly and most insects had located a plant within $10 \mathrm{~min}$ of release. No significant differences were noticed between the numbers of apterae on TMV 2 and those on GBPRS 15, GBPRS 66 and JL 24 over the 24 h period (Table $2 b$ ). However, during the first two h, significantly more insects were counted on EC 36892 than TMV 2, a distinct preference for the resistant genotype. At and between 4 and $8 \mathrm{~h}$ there was a shift away from the resistant genotype with similar numbers found on each genotype (Fig. 4). At 10 and $24 \mathrm{~h}$ the continuing move from EC 36892 led to significantly lower numbers on the resistant genotype.

\section{Discussion}

The results indicate that the following genotypes, NC Ac 343, GBPRS 15 and EC 36892, showed varying degrees of field and screenhouse resistance to $A$. craccivora by reducing growth 
Table 2a. Alate numbers on groundnut genotype TMV 2 and 4 other groundnut genotypes (23-26 DAS) over 24 h (Significant differences $* P<0.05 * * P<0.01$ )

\begin{tabular}{|c|c|c|c|c|c|c|c|c|}
\hline $\begin{array}{l}\text { Time } \\
\text { (h) }\end{array}$ & $\begin{array}{l}\text { No. on } \\
\text { TMV } 2\end{array}$ & $\begin{array}{c}\text { No. on } \\
\text { GBPRS } \\
66\end{array}$ & $x^{2}$ & & $\begin{array}{l}\text { No. on } \\
\text { TMV } 2\end{array}$ & $\begin{array}{c}\text { No. on } \\
\text { GBPRS } \\
15\end{array}$ & $X^{2}$ & \\
\hline 1 & 190 & 142 & 6.78 & $>\operatorname{TMV} 2^{* *}$ & 237 & 226 & 0.21 & NS \\
\hline 2 & 280 & 238 & 3.26 & NS & 215 & 236 & 0.88 & NS \\
\hline 4 & 209 & 262 & 5.16 & $>$ GBPRS $66^{*}$ & 229 & 241 & 0.25 & NS \\
\hline 6 & 194 & 184 & 0.21 & NS & 233 & 248 & 0.40 & NS \\
\hline 8 & 254 & 157 & 23.74 & $>\operatorname{TMV} 2^{* *}$ & 234 & 212 & 0.99 & NS \\
\hline 10 & 201 & 176 & 1.52 & NS & 180 & 166 & 0.48 & NS \\
\hline 24 & 162 & 216 & 7.58 & $>$ GBPRS $66^{* *}$ & 215 & 195 & 0.87 & NS \\
\hline $\begin{array}{l}\text { Time } \\
\text { (h) }\end{array}$ & $\begin{array}{l}\text { No. on } \\
\text { TMV } 2\end{array}$ & $\begin{array}{l}\text { No. on } \\
\text { JL } 24\end{array}$ & $X^{2}$ & & $\begin{array}{l}\text { No. on } \\
\text { TMV } 2\end{array}$ & $\begin{array}{c}\text { No. on } \\
\text { NC AC } \\
343\end{array}$ & $x^{2}$ & \\
\hline 1 & 261 & 244 & 0.50 & NS & 195 & 173 & 1.19 & NS \\
\hline 2 & 244 & 289 & 3.65 & NS & 268 & 241 & 1.33 & NS \\
\hline 4 & 273 & 286 & 0.25 & NS & 271 & 235 & 2.43 & NS \\
\hline 6 & 252 & 241 & 0.19 & NS & 255 & 238 & 0.51 & NS \\
\hline 8 & 230 & 238 & 0.10 & NS & 253 & 252 & 0.00 & NS \\
\hline 10 & 201 & 218 & 0.58 & NS & 170 & 184 & 0.46 & NS \\
\hline 24 & 241 & 255 & 0.34 & NS & 278 & 256 & 0.82 & NS \\
\hline
\end{tabular}

Table $2 b$. Apterae numbers on groundnut genotype TMV 2 and 4 other groundnut genotypes (23-26 DAS) over $24 \mathrm{~h}$ period (Significant difference $* P>0.05$ )

\begin{tabular}{|c|c|c|c|c|c|c|c|c|}
\hline $\begin{array}{l}\text { Time } \\
\text { (h) }\end{array}$ & $\begin{array}{l}\text { No. on } \\
\text { TMV } 2\end{array}$ & $\begin{array}{c}\text { No. on } \\
\text { GBPRS } \\
66\end{array}$ & $\mathrm{x}^{2}$ & & $\begin{array}{l}\text { No. on } \\
\text { TMV } 2\end{array}$ & $\begin{array}{c}\text { No. on } \\
\text { GBPRS } \\
15\end{array}$ & $X^{2}$ & \\
\hline 1 & 132 & 141 & 0.23 & NS & 107 & 115 & 0.22 & NS \\
\hline 2 & 132 & 147 & 0.70 & NS & 113 & 122 & 0.27 & NS \\
\hline 4 & 129 & 133 & 0.03 & NS & 105 & 121 & 0.99 & NS \\
\hline 6 & 121 & 127 & 0.10 & NS & 100 & 115 & 0.91 & NS \\
\hline 8 & 124 & 132 & 0.19 & NS & 99 & 110 & 0.47 & NS \\
\hline 10 & 114 & 121 & 0.15 & NS & 99 & 108 & 0.30 & NS \\
\hline 12 & 107 & 119 & 0.53 & NS & 105 & 106 & 0.00 & NS \\
\hline $\begin{array}{l}\text { Time } \\
\text { (h) }\end{array}$ & $\begin{array}{l}\text { No. on } \\
\text { TMV } 2\end{array}$ & $\begin{array}{l}\text { No. on } \\
\text { JL } 24\end{array}$ & $x^{2}$ & & $\begin{array}{l}\text { No. on } \\
\text { TMV } 2\end{array}$ & $\begin{array}{c}\text { No. on } \\
\text { NC Ac } \\
343\end{array}$ & $x^{2}$ & \\
\hline 1 & 158 & 144 & 0.55 & NS & 122 & 108 & 0.74 & NS \\
\hline 2 & 150 & 150 & 0.00 & NS & 123 & 106 & 1.17 & NS \\
\hline 4 & 148 & 152 & 0.03 & NS & 120 & 101 & 1.46 & NS \\
\hline 6 & 150 & 143 & 0.12 & NS & 123 & 95 & 3.34 & NS \\
\hline 8 & 149 & 133 & 0.79 & NS & 106 & 84 & 2.32 & NS \\
\hline 10 & 139 & 132 & 0.13 & NS & 102 & 69 & 5.98 & $>$ TMV 2 \\
\hline 12 & 117 & 101 & 1.03 & NS & 77 & 72 & 0.10 & NS \\
\hline
\end{tabular}

and fecundity with the greatest reduction in fecundity occurring on the latter. Resistance as measured by reduced fecundity was sustained in these genotypes up to 43 DAS, being being relevant to the control of the aphid and the containment of some groundnut virus diseases during the most vulnerable stage of the crop. The fecundity of apterae on plants $<20$ DAS 


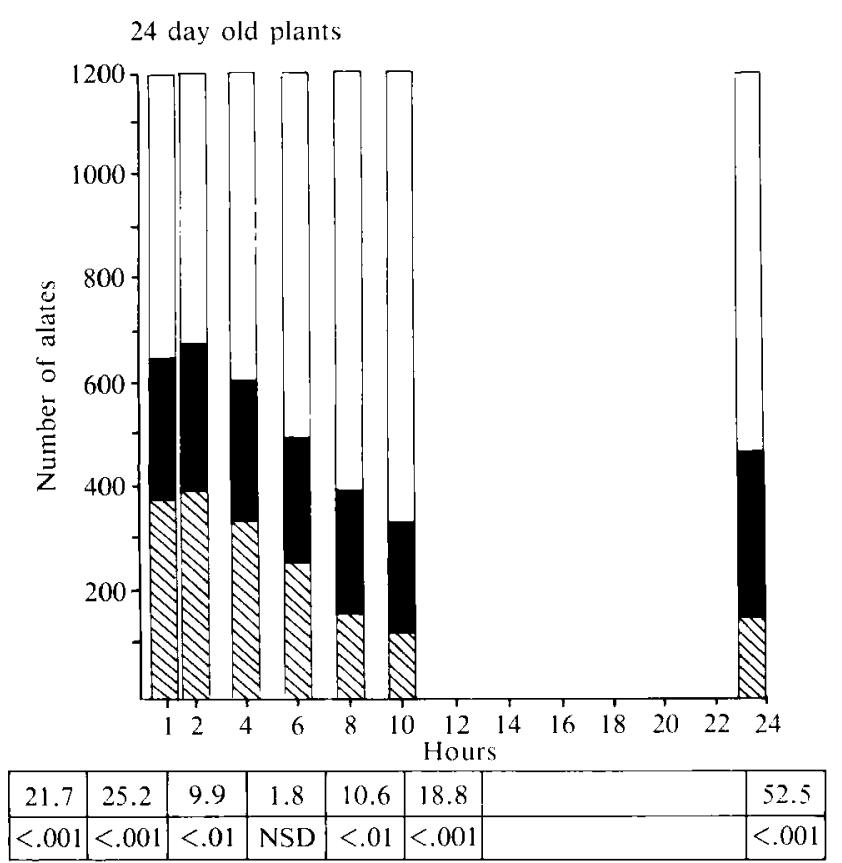

Fig. 3. The distribution of alates over a period of $24 \mathrm{~h}$ after release: TMV 2 EC 36892 証, Neither Genotype

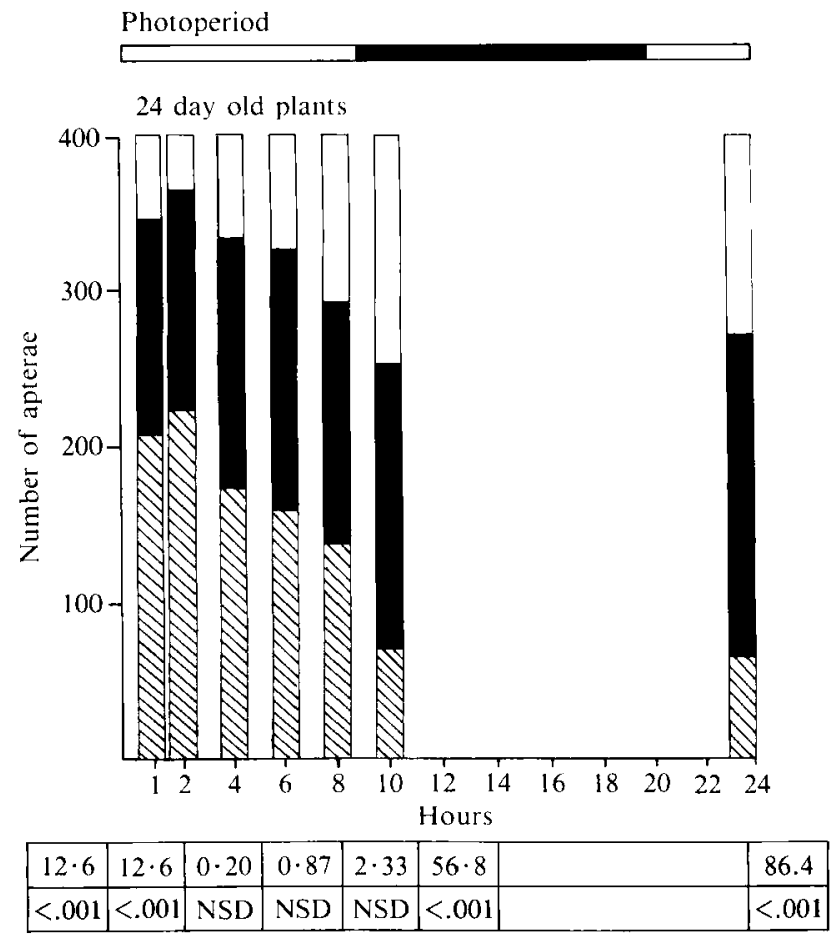

Fig. 4. The distribution of apterae over a period of $24 \mathrm{~h}$ after release: TMV 2 Neither Genotype $\square$. 
of genotype JL 24 in screenhouse conditions was similar to those on $<20$ DAS plants of TMV 2 but it was reduced on older plants of JL 24 (25-43 DAS). This suggests that the susceptibility of this genotype decreases rapidly with increasing plant age and further trials will be necessary to determine the status of JL 24 at different ages.

There was no evidence of landing deterrents in any of the genotypes because the numbers of alates counted during field sampling were similar or higher on all test genotypes when compared with TMV 2.

The selection tests in the screenhouse showed that $A$. craccivora was not inhibited from landing or walking onto any of the test genotypes, for example, more aphids were initially found on EC 36892 than on TMV 2. It is possible that physical or volatile chemical characteristics of EC 36892 make it more attractive to aphids approaching from a distance. However, the selection tests show that after approximately 4-6 h aphids move off EC 36892. One explanation for this behaviour could be that the insects detect one or more resistance factors, i.e. the presence of a deterrent or absence of an essential constituent of this genotype and leave to find a more suitable host. Before leaving the resistant plant the alates may deposit nymphs and results from field sampling suggests that this appears to be the case because large numbers of nymphs were counted on EC 36892, especially at 16 DAS. Their growth and fecundity will presumably be reduced when compared to those on TMV 2 so that the development of this and subsequent generations would be retarded. Presumably this would lead to smaller numbers of aphids on EC 36892 than on TMV 2 and could reduce the spread of apterae and possible virus infection within the crop.

In an attempt to determine the resistant factor(s) which inhibit colonisation and reduce fecundity, the behavioural steps made by an aphid following landing or walking onto a plant should be considered. After landing on a plant, aphids test the plant surface with mechanoreceptors on the tip of their rostrum (Tjallingii, 1978) and penetrate the plant tissues with their stylets (Pollard, 1973). Gustatory discrimination may then occur when ingested fluids reach the epipharyngeal organ, a chemosensory structure in the dorsal wall of the food canal (Wensler \& Filshie, 1969). As mentioned previously the selection tests using alates and apterae showed that in a $24 \mathrm{~h}$ period more insects left the resistant genotype than the susceptible one. Since most aphid species must probe into the plant to find a specific feeding site, the phloem sieve element, it is probable that the aphids leave because they have not obtained suitable probing or feeding stimuli or have encountered probing or feeding deterrents. Interference with phloem location and/or feeding on the resistant genotype could also explain the low rates of development and reproduction in the performance tests. Being less 'fit' they may have a low capacity to survive harsh conditions (Dixon, 1985) and this may account for the greater field mortality of nymphs on EC 36892 (85\% reduction) compared to those on TMV 2 (61\% reduction) following heavy rain on 15 July 1988.

The probing behaviour of this aphid on the resistant and susceptible genotypes is, therefore, the next step in this investigation. Studies include electronic monitoring of stylet penetration (Tjallingii, 1988) to determine relative probing frequencies, the time required for phloem location and lengths of phloem ingestion (F. M. Kimmins, in preparation) and chemical analysis of TMV 2 and EC 36892 (R. J. Grayer, in preparation).

\section{Acknowledgements}

The authors would like to thank Dr J. A. Wighțman for editing the manuscript and for providing facilities at ICRISAT. Also the members of the Pulse Entomology Department for their help and assistance during the field trip. 


\section{References}

Amin, P. W. (1985). Resistance of wild species of groundnut to insect and mite pests. In Cytogenetics of Arachis. Proceedings of International Workshop. 31st October - 2nd November 1983, ICRISAT Centre, Patancheru, A.P. India.

Anon. (1987). International Crops Research Institute for the Semi-Arid Tropics, Annual Report 1986. Patancheru, A.P. 502 324, India: ICRISAT.

Anon. (1988). International Crops Research Institute for the Semi-Arid Tropics, Annual Report 1987. Patancheru, A. P. 502 324, India: ICRISAT.

Dixon, A. F. G. (1985). Aphid Ecology, p. 31. Glasgow and London: Blackie.

Evans, A. C. (1954). Groundnut rosette disease in Tanganyika. I. Field studies. Annals of Applied Biology 41, 189-206.

Feakin, S. D. (1973). (Ed.). Pest control in groundnuts. 3rd Edition, PANS manual No. 2, p. 123. London: U.K. Centre for Overseas Pest Research.

Givovich, A., Weibull, J. \& Pettersson, J. (1988). Cowpea aphid performance and behaviour on two resistant cowpea lines. Entomologia experimentalis et applicata 49, 259-264.

Heathcote, G. D. (1972). Evaluating aphid populations on plants. In Aphid Technology, pp. 105-145. Ed. H. F. van Emden. Academic press.

Kennedy, J. S., Ibbotson, A. \& Booth, C. O. (1950). The distribution of aphid infestation in relation to leaf age. I. Myzus persicae (Sulz.) and Aphis fabae Scop. on spindle trees and sugar beet plants. Annals of Applied Biology 32, 651-679.

MacFoy, C. C. A. \& Dabrowski, Z. T. (1984). Preliminary studies on cowpea resistance to Aphis craccivora Koch (Homoptera: Aphididae). Zoologie angew andt Entomologie 97, 202-209.

Nobel, M. D. (1958). A simplified clip cage for aphid investigation. Canadian Entomologist 90, 760.

Pollard, D. G. (1973). Plant penetration by feeding aphids (Hemiptera: Aphidoidea): a review. Bulletin of Entomological Research 62, 631-714.

Schnorbach, H. J. (1983). Der Einfluss von Bedsiedlungs-und Einstechverhalten auf Beginn und Verlauf der Nahrungsaufnahme bei Blattlausgruppen an Wirtspflanze und Kunstlicher Diat (Aphididae: Homoptera). Thesis, University of Bonn, Faculty of Mathematics and Natural Science. $211 \mathrm{pp}$.

Tjallingii, W. F. (1978). Mechanoreceptors of the aphid labium. Entomologia experimentalis et applicata 24, 731-737.

Tjallingii, W. F. (1988). Electronic monitoring of stylet penetration activities. In Aphids, their biology, natural enemies and control. World Crop Pests Vol. 2B, pp. 95-108. Eds A. K. Minks and P. Harrewijn. Elsevier.

Wensler, R. J. D. \& Filshie, B. K. (1969). Gustatory sense organs in the food canal of aphids. Journal of Morphology 129, 473-492.

Wightman, J. A. \& Amin, P. W. (1988). Groundnut pests and their control in the Semi-Arid Tropics. Tropical Pest Management 34, 218-226.

(Received 15 November 1989) 